\title{
Leisingera aquimarina sp. nov., isolated from a marine electroactive biofilm, and emended descriptions of Leisingera methylohalidivorans Schaefer et al. 2002, Phaeobacter daeponensis Yoon et al. 2007 and Phaeobacter inhibens Martens et al. 2006
}

Correspondence

Ilse Vandecandelaere

Ilse.Vandecandelaere@UGent.be
Ilse Vandecandelaere, ${ }^{1}$ Eveline Segaert, ${ }^{1}$ Alfonso Mollica, ${ }^{2}$ Marco Faimali ${ }^{2}$
and Peter Vandamme ${ }^{1}$

${ }^{1}$ Laboratorium voor Microbiologie, Vakgroep Biochemie, Fysiologie en Microbiologie, Universiteit Gent, K.L. Ledeganckstraat 35, B-9000 Gent, Belgium

${ }^{2}$ Instituto di Scienze Marine - Consiglio Nazionale delle Ricerche (ISMAR-CNR), Via de Marini 6, 16149 Genoa, Italy

\begin{abstract}
Strain LMG $24366^{\top}$ was isolated from a marine electroactive biofilm grown on a stainless steel cathode (Genova, Italy) and was investigated by using a polyphasic taxonomic approach. This study demonstrated that strain LMG $24366^{\top}$ represents a novel species within the genus Leisingera, which shared $98.9 \% 16 \mathrm{~S}$ rRNA gene similarity with its nearest phylogenetic neighbour, Leisingera methylohalidivorans. Strain LMG $24366^{\top}$ grew on betaine $(1 \mathrm{mM})$ as a sole carbon source, whereas no growth was observed on L-methionine (10 mM). The phenotypic and genotypic analyses showed that strain LMG $24366^{\top}$ could be differentiated from established Leisingera species and that it represented a novel species, for which the name Leisingera aquimarina sp. nov. is proposed. The type strain is LMG $24366^{\top}\left(=\right.$ CCUG $\left.55860^{\top}\right)$ and has a DNA G $+C$ content of $61.4 \mathrm{~mol} \%$.
\end{abstract}

The genus Leisingera was created by Schaefer et al. (2002) to accommodate Leisingera methylohalidivorans. The only species of this genus was isolated from a tide pool off the coast of California and was able to grow on methyl bromide as a sole energy and carbon source (Schaefer et al., 2002). Although oceans act as a sink for methyl bromide (Yvon \& Butler, 1996), it was the first species shown to be able to grow on methyl bromide. Growth of L. methylohalidivorans has also been observed on methyl chloride, methyl iodide and methionine. These data indicate a role for L. methylohalidivorans in the degradation of methyl halides and thus in the release of bromide and chlorine atoms in the stratosphere, which contributes to the catalytic destruction of ozone (Butler, 1999).

The genus Leisingera is a member of the Roseobacter lineage of the Alphaproteobacteria. This lineage is one of the most abundant marine groups (González et al., 2000), as Roseobacter species can constitute up to $20 \%$ of coastal bacterioplankton communities and are found in almost all marine environments (Buchan et al., 2005).

The GenBank/EMBL/DDBJ accession number for the 16S rRNA gene sequence of strain LMG $24366^{\top}$ is $A M 900415$.
The present study formed part of an analysis of the microbial diversity of a marine electroactive biofilm grown on a stainless steel cathode [EA BIOFILMS-508866 (NEST)], exposed to natural seawater at the ISMAR-CNR Marine Station, located in the port of Genoa, Italy (Faimali et al., 2008; Vandecandelaere et al., 2008). The biofilm was removed from the stainless steel cathode by sonication (Branson 3200) (90 s) in a sterile plastic tube containing $30 \mathrm{ml} 0.85 \% \mathrm{NaCl}$ solution. Diluted cell suspensions $\left(10^{-1}\right.$ to $10^{-6}$ ) were inoculated on marine agar 2216 (MA; Difco) and incubated aerobically at $20{ }^{\circ} \mathrm{C}$ for several days. Pure cultures were obtained and isolates were stored at -20 or $-80{ }^{\circ} \mathrm{C}$ using MicroBank vials.

Whole-cell fatty acid methyl ester analysis, performed as described by Mergaert et al. (2001), indicated that strain LMG $24366^{\mathrm{T}}$ belonged to the Alphaproteobacteria. The predominant fatty acids were $\mathrm{C}_{10: 0} 3-\mathrm{OH}(2.0 \%), \mathrm{C}_{12: 0} 3$ $\mathrm{OH}(2.1 \%), \mathrm{C}_{16: 0}(3.5 \%), \mathrm{C}_{16: 0} 2-\mathrm{OH}(4.2 \%), \mathrm{C}_{14: 1}$ iso $\mathrm{E}$ (11.6\%), $\mathrm{C}_{18: 1} \omega 7 c(71.6 \%)$ and an unknown fatty acid of equivalent chain-length $11.799(2.7 \%)$. The remaining fatty acids constituted minor fractions only $(<1.0 \%)$. The predominant fatty acids observed were very similar to those of Phaeobacter daeponensis, Phaeobacter gallaeciensis, 
Phaeobacter inhibens and L. methylohalidivorans (Yoon et al., 2007), indicating that strain LMG $24366^{\mathrm{T}}$ was closely related to Phaeobacter species and to L. methylohalidivorans.

DNA was extracted according to Pitcher et al. (1989) and an almost-complete 16S rRNA gene sequence was obtained (1396 bp) using the universal primers pA (5'-AGAGTTTGATCCTGGCTCAG- $\left.3^{\prime}\right)$ and $\mathrm{pH}$ (5'-AAGGAGGTGATCCAGCCGCA-3') (Edwards et al., 1989), as described by Mergaert et al. (2001). The FASTA program was used to find the most similar sequences. These almost-complete $16 \mathrm{~S}$ rRNA gene sequences (1248-1465 bp) were aligned using CLUSTAL_X (Thompson et al., 1997) and a neighbour-joining dendrogram was constructed (Saitou \& Nei, 1987) using BioNumerics 4.61 software (Applied Maths) (Fig. 1).

The numerical analysis indicated that the nearest phylogenetic neighbour of strain LMG $24366^{\mathrm{T}}$ was L. methylohalidivorans LMG $23656^{\mathrm{T}}$ with $98.9 \%$ 16S rRNA gene sequence similarity. Members of the genus Phaeobacter $(P$. daeponensis LMG $24139^{\mathrm{T}}, P$. inhibens LMG $22475^{\mathrm{T}}$ and $P$. gallaeciensis LMG 23163 ${ }^{\mathrm{T}}$ ) (Martens et al., 2006; Yoon et al., 2007) were also closely related to strain LMG $24366^{\mathrm{T}}$, with 16S rRNA gene sequence similarities of 96.9-97.2\%.

Strains LMG $24366^{\mathrm{T}}$, L. methylohalidivorans LMG $23656^{\mathrm{T}}$, P. gallaeciensis LMG $23163^{\mathrm{T}}$ and P. inhibens LMG $22475^{\mathrm{T}}$ were investigated by using repetitive-PCR fingerprinting using the BOX-A1R-primer 5'-CTACGGCAAGGCGACGCTGACG-3' (Rademaker et al., 2000; Versalovic et al., 1994). Numerical analysis, using BioNumerics $4.61 \mathrm{soft}$ ware showed that strain LMG $24366^{\mathrm{T}}$ could be distinguished from its nearest phylogenetic neighbours (Fig. 2).

The DNA G + C content of strain LMG $24366^{\mathrm{T}}$ was determined. DNA was enzymically degraded into nucleosides as described by Mesbah et al. (1989). The nucleoside mixture obtained was separated using a Water Breeze HPLC system and Xbridge Shield RP18 column thermostabilized at $37{ }^{\circ} \mathrm{C}$. The solvent used was $0.02 \mathrm{M}$ $\mathrm{NH}_{4} \mathrm{H}_{2} \mathrm{PO}_{4}$ (pH 4.0) with $1.5 \%$ acetonitrile. Non-methylated lambda phage (Sigma) and Escherichia coli LMG 2093 DNA were used as calibration reference and control, respectively. The DNA G $+\mathrm{C}$ content of LMG $24366^{\mathrm{T}}$ was $61.4 \mathrm{~mol} \%$, which correlates with that of the genus Leisingera as described by Schaefer et al. (2002).

DNA-DNA hybridization experiments were carried out with photobiotin-labelled probes in microplate wells, as described by Ezaki et al. (1989), using a HTS7000 Bio Assay Reader (Perkin Elmer) for the fluorescence measurements. The hybridization temperature used was $45{ }^{\circ} \mathrm{C}$ and reciprocal reactions were performed for each pair of strains. The mean DNA-DNA hybridization value between strain LMG $24366^{\mathrm{T}}$ and its nearest phylogenetic neighbour, $L$. methylohalidivorans LMG $23656^{\mathrm{T}}$, was $56 \pm 2 \%$; the mean DNA-DNA hybridization value between LMG $24366^{\mathrm{T}}$ and P. gallaeciensis LMG $23163^{\mathrm{T}}$ was very low $(2 \pm 0 \%)$. These data indicated that LMG $24366^{\mathrm{T}}$ represents a novel species within the genus Leisingera (Wayne et al., 1987).
The following morphological, physiological and biochemical characteristics were evaluated for strain LMG $24366^{\mathrm{T}}$. Colony morphology was determined after 4 days incubation at $20{ }^{\circ} \mathrm{C}$ on MA. Cells were tested for their Gram reaction and the presence of catalase and oxidase activity.

Growth was examined on nutrient agar (NA), trypticase soy agar (TSA), R2A and peptone/yeast extract/glucose (PYG) agar (Tan \& Rüger, 1999). Growth on L-methionine $(10 \mathrm{mM})$ and betaine $(1 \mathrm{mM})$ was tested as described by Martens et al. (2006). The optimal salinity and the optimal growth temperature were determined using R2A supplemented with $1-20 \% \mathrm{NaCl}$, incubated for 2 weeks at $20{ }^{\circ} \mathrm{C}$, and MA incubated at $4-45{ }^{\circ} \mathrm{C}$ for 2 weeks, respectively. The effect of $\mathrm{pH}$ on growth was analysed using marine broth 2216 (Difco) with a pH that ranged from 5.0 to 10.0 (at intervals of $0.5 \mathrm{pH}$ units), with incubation at $20{ }^{\circ} \mathrm{C}$ for 7 days.

Degradation of casein and chitin (Reichenbach \& Dworkin, 1981), DNA [using DNA agar (Difco) containing 0.01\% toluidine blue (Merck)], starch and L-tyrosine (Barrow \& Feltham, 1993) was tested and the reactions were read after 5 days incubation at $20^{\circ} \mathrm{C}$. Strain LMG $24366^{\mathrm{T}}$ was inoculated on Sierra's medium to determine its lipolytic activity and incubated for 10 days at $20{ }^{\circ} \mathrm{C}$ (Sierra, 1957).

The susceptibility to the following antibiotics (Oxoid) was examined on MA plates using the disc diffusion method: cefoxitin $(30 \mu \mathrm{g})$, gentamicin $(30 \mu \mathrm{g})$, erythromycin $(15 \mu \mathrm{g})$, tetracycline $(30 \mu \mathrm{g})$, streptomycin $(25 \mu \mathrm{g})$, vancomycin $(30 \mu \mathrm{g})$, trimethoprim $(1.25 \mu \mathrm{g})$ and clindamycin $(2 \mu \mathrm{g})$. Results were read after 5 days incubation at $20{ }^{\circ} \mathrm{C}$.

Biochemical characteristics from commercial microtest galleries (API ZYM and API 20NE; bioMérieux) were studied according to the manufacturer's instructions. API ZYM was read after $4 \mathrm{~h}$ incubation at $20{ }^{\circ} \mathrm{C}$, whereas API $20 \mathrm{NE}$ was read after $48 \mathrm{~h}$ incubation at $20{ }^{\circ} \mathrm{C}$.

The cell morphology of strain LMG $24366^{\mathrm{T}}$ was determined by using transmission electron microscopy. Cells were negatively stained with $2 \%$ uranyl acetate. Ultrathin sections were prepared and analysed as described by Mast et al. (2005) (Fig. 3).

The results of the phenotypic tests are given in Table 1 . Strain LMG $24366^{\mathrm{T}}$ could be differentiated from $L$. methylohalidivorans and Phaeobacter species. On the basis of the phylogenetic, genomic and phenotypic data, LMG $24366^{\mathrm{T}}$ represents a novel species within the genus Leisingera, for which the name Leisingera aquimarina sp. nov. is proposed.

\section{Description of Leisingera aquimarina sp. nov.}

Leisingera aquimarina (a.qui'ma.ri'na. L. fem. n. aqua water; L. adj. marinus from the sea; N.L. fem. adj. aquimarina from seawater).

Cells are ovoid $(1 \times 1.4 \mu \mathrm{m})$, Gram-negative and motile by means of a single polar flagellum. Poly- $\beta$-hydroxybutyrate inclusion bodies are present. Colonies are dark beige-pink, 


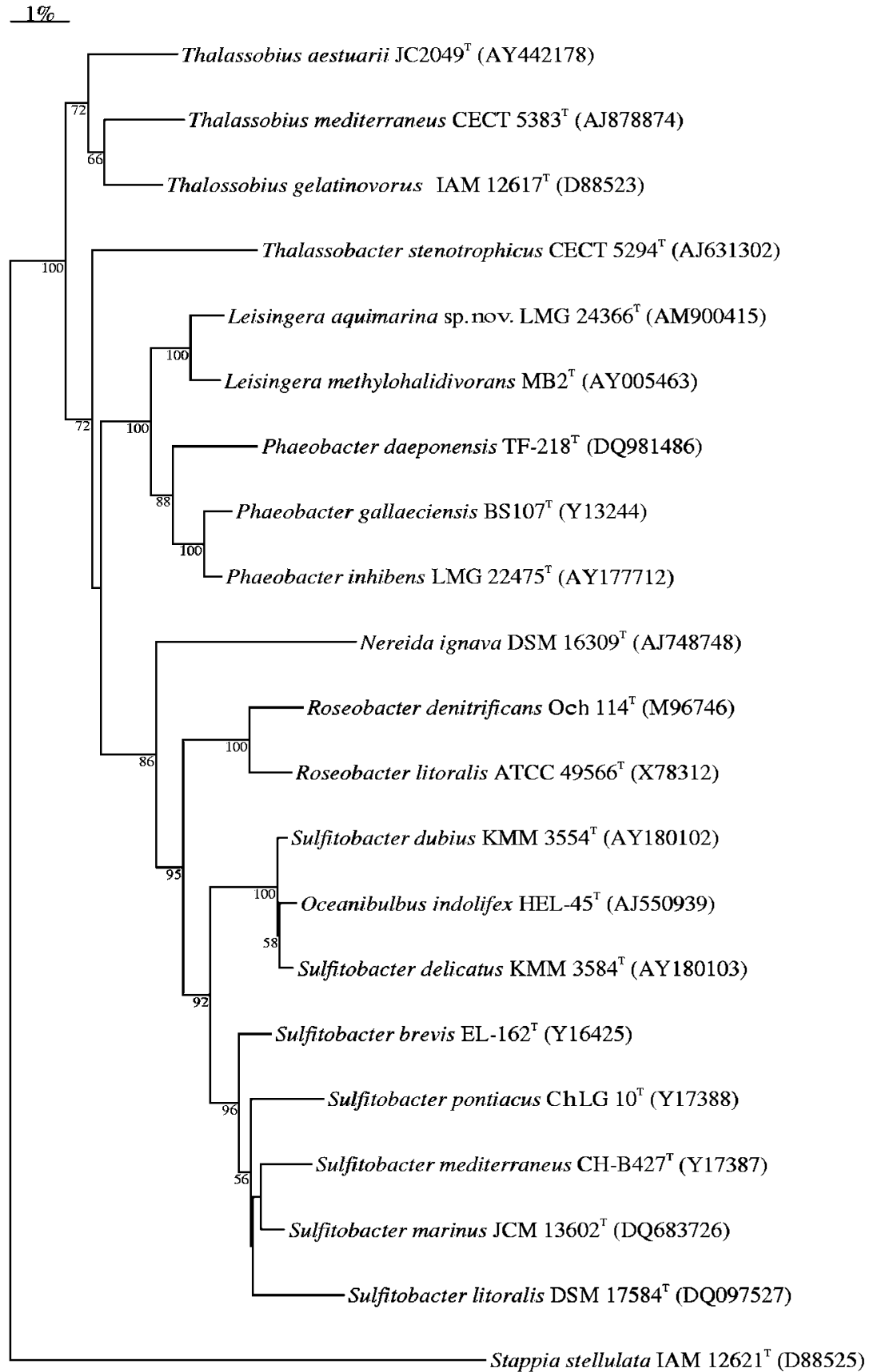

Fig. 1. Neighbour-joining dendrogram depicting the 16S rRNA gene sequences of strain LMG $24366^{\top}$ (Leisingera aquimarina sp. nov.) and related species. Bar, $1 \% 16 \mathrm{~S}$ rRNA gene sequence diversity. Bootstrap percentages (1000 replicates) above $50 \%$ are shown. round and $1-2 \mathrm{~mm}$ in diameter after 3 days incubation on MA. Growth occurs after 2 days incubation at $20{ }^{\circ} \mathrm{C}$ on MA, but not on R2A, NA, TSA or PYG. Temperature range for growth is $4-37{ }^{\circ} \mathrm{C}$; no growth occurs at $40{ }^{\circ} \mathrm{C}$ or higher. $\mathrm{NaCl}$ range for growth is $1-7 \% \mathrm{pH}$ range for growth is 5.5-9.0; optimal pH for growth is 6.5-8. Growth occurs on betaine $(1 \mathrm{mM})$ as a sole carbon source, but not on Lmethionine $(10 \mathrm{mM})$. Catalase- and oxidase-positive. Degradation of gelatin is weakly positive; does not degrade tyrosine, DNA, starch, casein, chitin, aesculin or Tween 80 . Positive for leucine arylamidase activity; weak alkaline phosphatase, esterase lipase (C8) and naphthol-AS-BI- phosphohydrolase activities. No activity is detected for esterase (C4), valine arylamidase, acid phosphatase, $\alpha$ galactosidase, $\beta$-glucuronidase, $\alpha$-glucosidase, $\beta$-glucosidase, $N$-acetyl- $\beta$-glucosaminidase, $\alpha$-mannosidase, lipase (C14), cystine arylamidase, trypsin, $\alpha$-chymotrypsin, arginine dihydrolase, urease or $\alpha$-fucosidase. Nitrate is not reduced to nitrite or nitrogen. Indole is not produced and glucose is not fermented. Does not assimilate D-glucose, Larabinose, D-mannose, D-mannitol, $\mathrm{N}$-acetylglucosamine, maltose, potassium gluconate, capric acid, adipic acid, malate, citrate or phenylacetic acid. Susceptible to cefoxitin $(30 \mu \mathrm{g})$, erythromycin $(15 \mu \mathrm{g})$, tetracycline $(30 \mu \mathrm{g})$ and 


\section{Phaeobacter gallaeciensis}

Leisingera methylohalidivorans

Phaeobacter inhibens

Leisingera aquimarina sp. nov.
Fig. 2. BOX-PCR fingerprints of strain $L M G$ $24366^{\top}$ (Leisingera aquimarina sp. nov.) and related strains. streptomycin $(25 \mu \mathrm{g})$. Resistant to vancomycin $(30 \mu \mathrm{g})$, trimethoprim $(1.25 \mu \mathrm{g})$, clindamycin $(2 \mu \mathrm{g})$ and gentamicin $(30 \mu \mathrm{g})$. Dominant fatty acids are $\mathrm{C}_{10: 0} 3-\mathrm{OH}, \mathrm{C}_{12: 0} 3-$ $\mathrm{OH}, \mathrm{C}_{16: 0}, \mathrm{C}_{16: 0} 2-\mathrm{OH}, \mathrm{C}_{14: 1}$ iso $\mathrm{E}, \mathrm{C}_{18: 1} \omega 7 c$ and an unknown fatty acid of equivalent chain-length of 11.799; other fatty acids constitute trace amounts only $(<1.0 \%)$. The DNA G+G content of the type strain is $61.4 \mathrm{~mol} \%$.

The type strain, LMG $24366^{\mathrm{T}}$ (=CCUG $55860^{\mathrm{T}}$ ), was isolated from a marine electroactive biofilm grown on a stainless steel cathode (Genoa, Italy).

\section{Emended description of the genus Leisingera Schaefer et al. 2002}

The description is as given by Schaefer et al. (2002) and Martens et al. (2006) with the following additions. Do not degrade tyrosine, casein or DNA. Do not hydrolyse aesculin or gelatin. No indole production or fermentation of glucose. Do not grow on NA, R2A or PYG. Positive for leucine arylamidase activity. No activity is detected for esterase (C4), esterase lipase (C8), lipase (C14), cystine arylamidase, trypsin, $\alpha$-chymotrypsin, acid phosphatase, $\alpha$-galactosidase, $\beta$-glucuronidase, $\alpha$-glucosidase, $N$-acetyl- $\beta$-glucosaminidase, $\alpha$-mannosidase, $\alpha$-fucosidase, arginine dihydrolase or urease. Do not assimilate D-mannose, D-mannitol, maltose, potassium gluconate, capric acid, adipic acid or phenylacetic acid. Susceptible to cefoxitin (30 $\mu \mathrm{g})$, erythromycin $(15 \mu \mathrm{g})$, streptomycin $(25 \mu \mathrm{g})$ and tetracycline $(30 \mu \mathrm{g})$. Resistant to vancomycin $(30 \mu \mathrm{g})$, trimethoprim $(1.25 \mu \mathrm{g})$ and clindamycin $(2 \mu \mathrm{g})$. The type species is Leisingera methylohalidivorans.

\section{Emended description of Leisingera methylohalidivorans Schaefer et al. 2002}

The description is as given by Schaefer et al. (2002) and Martens et al. (2006) with the following additions. Does not degrade tyrosine, casein or DNA. Does not hydrolyse aesculin or gelatin. No indole production or fermentation of glucose. Grows weakly on TSA; does not grow on NA, R2A or PYG. Positive for leucine arylamidase activity; weak valine arylamidase and naphthol-AS-BI-phosphohydrolase activities. No activity is detected for alkaline phosphatase, esterase (C4), esterase lipase (C8), lipase (C14), cystine arylamidase, trypsin, $\alpha$-chymotrypsin, acid phosphatase, $\alpha$ galactosidase, $\beta$-galactosidase, $\beta$-glucuronidase, $\alpha$-glucosidase, $N$-acetyl- $\beta$-glucosaminidase, $\alpha$-mannosidase, $\alpha$-fucosidase, arginine dihydrolase or urease. Does not assimilate D-mannose, D-mannitol, maltose, potassium gluconate, capric acid, adipic acid or phenylacetic acid. Susceptible to cefoxitin $(30 \mu \mathrm{g})$, erythromycin $(15 \mu \mathrm{g})$, streptomycin $(25 \mu \mathrm{g})$ and tetracycline $(30 \mu \mathrm{g})$. Intermediately susceptible to gentamicin $(10 \mu \mathrm{g})$. Resistant to vancomycin $(30 \mu \mathrm{g})$, trimethoprim $(1.25 \mu \mathrm{g})$ and clindamycin $(2 \mu \mathrm{g})$.

\section{Emended description of Phaeobacter inhibens Martens et al. 2006}

The description is as given by Martens et al. (2006) with the following additions. Grows weakly on TSA; does not grow on NA, PYG or R2A. Does not hydrolyse DNA or aesculin. No fermentation of glucose. Positive for leucine arylamidase activity; weak acid phosphatase and $\alpha$ glucosidase activities. No activity is detected for esterase (C4), esterase lipase (C8), lipase (C14), valine arylamidase, cystine arylamidase, trypsin, $\alpha$-chymotrypsin, naphtholAS-BI-phosphohydrolase, $\alpha$-galactosidase, $\beta$-galactosidase, $\beta$-glucuronidase, $\beta$-glucosidase, $N$-acetyl- $\beta$-glucosaminidase, $\alpha$-mannosidase, $\alpha$-fucosidase, arginine dihydrolase or urease. Susceptible to cefoxitin $(30 \mu \mathrm{g})$. Intermediately susceptible to erythromycin $(15 \mu \mathrm{g})$ and streptomycin $(25 \mu \mathrm{g})$. Resistant to tetracycline $(30 \mu \mathrm{g})$, gentamicin $(10 \mu \mathrm{g})$, vancomycin $(30 \mu \mathrm{g})$, trimethoprim $(1.25 \mu \mathrm{g})$ and clindamycin $(2 \mu \mathrm{g})$.

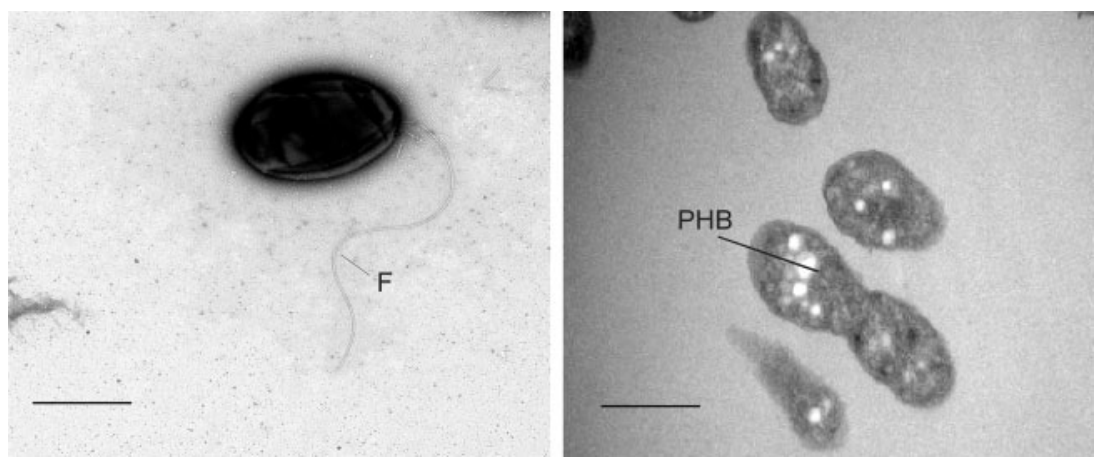

Fig. 3. Electron micrographs of cells of $L M G$ $24366^{\top}$, showing a polar flagellum ( $\mathrm{F}$; left) and poly- $\beta$-hydroxybutyrate (PHB) inclusion bodies (right). Bars, $0.5 \mu \mathrm{m}$. 
Table 1. Phenotypic characteristics of Leisingera aquimarina sp. nov., Leisingera methylohalidivorans and Phaeobacter species

Strains: 1, LMG $24366^{\mathrm{T}}$ (Leisingera aquimarina sp. nov.); 2, L. methylohalidivorans LMG $23656^{\mathrm{T}}$ (data from Schaefer et al., 2002; Martens et al., 2006); 3, P. inhibens LMG 22475 ${ }^{\mathrm{T}}$ (Martens et al., 2006); 4, P. gallaeciensis LMG 23163 ${ }^{\mathrm{T}}$ (Ruiz-Ponte et al., 1998; Martens et al., 2006); 5, $P$. daeponensis LMG $24139^{\mathrm{T}}$ (Yoon et al., 2007). All strains are Gram-negative, grow in $2 \% \mathrm{NaCl}$, and are oxidase- and catalase-positive and susceptible to streptomycin $(25 \mu \mathrm{g})$. +, Positive; -, negative; w, weakly positive; I, intermediate susceptibility to an antibiotic; ND, no data available.

\begin{tabular}{|c|c|c|c|c|c|}
\hline Characteristic & 1 & 2 & 3 & 4 & 5 \\
\hline Origin & Marine $\mathrm{EAB}^{\star}$, Italy & Tidal pool, USA & $\begin{array}{l}\text { Tidal flat, } \\
\text { Germany }\end{array}$ & Scallop, Spain & Tidal flat, Korea \\
\hline Colony colour & Dark beige-pink & Non-pigmented & Dark brown & Brown & Yellowish white \\
\hline \multicolumn{6}{|l|}{ Growth at: } \\
\hline $4{ }^{\circ} \mathrm{C}$ & + & + & + & - & + \\
\hline $40{ }^{\circ} \mathrm{C}$ & - & - & - & - & + \\
\hline \multicolumn{6}{|l|}{ Growth in $\mathrm{NaCl}$ at: } \\
\hline $1 \%$ & $\mathrm{~W}$ & - & + & + & + \\
\hline $7 \%$ & $\mathrm{~W}$ & - & + & + & + \\
\hline $10 \%$ & - & - & - & + & - \\
\hline \multicolumn{6}{|l|}{ Growth on: } \\
\hline NA & - & $-\dagger$ & $-\dagger$ & $\mathrm{ND}$ & $\mathrm{w} \dagger$ \\
\hline TSA & - & $\mathrm{w} \dagger$ & $\mathrm{w}^{\dagger}$ & ND & $\mathrm{w} \dagger$ \\
\hline \multicolumn{6}{|l|}{ Growth on: } \\
\hline Betaine & + & + & + & - & $+\dagger$ \\
\hline Methionine & - & + & + & + & $+\dagger$ \\
\hline \multicolumn{6}{|l|}{ Degradation of: } \\
\hline Tyrosine & - & $-\dagger$ & + & $-\dagger$ & + \\
\hline Starch & - & + & - & - & - \\
\hline Gelatin & $\mathrm{W}$ & $-\dagger$ & - & - & - \\
\hline Reduction of nitrate to nitrite & - & - & - & - & + \\
\hline \multicolumn{6}{|l|}{ Susceptibility to: } \\
\hline Erythromycin $(15 \mu \mathrm{g})$ & + & $+\dagger$ & $\mathrm{I} \dagger$ & + & $\mathrm{I} \dagger$ \\
\hline Tetracycline $(30 \mu \mathrm{g})$ & + & $+\dagger$ & $-\dagger$ & $\mathrm{ND}$ & - \\
\hline Gentamicin $(30 \mu \mathrm{g})$ & - & $\mathrm{I} \dagger$ & $-\dagger$ & + & + \\
\hline Vancomycin $(30 \mu \mathrm{g})$ & - & $-\dagger$ & $-\dagger$ & ND & $+\dagger$ \\
\hline \multicolumn{6}{|l|}{ Enzymic activity $\dagger$} \\
\hline Alkaline phosphatase & $\mathrm{W}$ & - & - & ND & + \\
\hline Esterase (C4) & - & - & - & ND & + \\
\hline Esterase lipase (C8) & $\mathrm{w}$ & - & - & ND & + \\
\hline Valine arylamidase & - & $\mathrm{w}$ & - & $\mathrm{ND}$ & - \\
\hline Acid phosphatase & - & - & $\mathrm{W}$ & $\mathrm{ND}$ & + \\
\hline Naphthol-AS-BI-phosphohydrolase & $\mathrm{W}$ & $\mathrm{W}$ & - & $\mathrm{ND}$ & - \\
\hline$\alpha$-Glucosidase & - & - & $\mathrm{W}$ & ND & - \\
\hline DNA G + C content $(\mathrm{mol} \%)$ & 61.4 & 60.5 & 55.7 & 58 & 64.9 \\
\hline
\end{tabular}

${ }^{\star}$ Electroactive biofilm.

$\dagger$ Data from this study.

\section{Emended description of Phaeobacter daeponensis Yoon et al. 2007}

The description is as given by Yoon et al. (2007) with the following additions. Grows weakly on TSA and NA; does not grow on PYG or R2A. Does not hydrolyse DNA. No fermentation of glucose. No activity is detected for urease. Susceptible to cefoxitin $(30 \mu \mathrm{g})$ and vancomycin $(30 \mu \mathrm{g})$. Intermediately susceptible to erythromycin $(15 \mu \mathrm{g})$. Resistant to trimethoprim $(1.25 \mu \mathrm{g})$ and clindamycin $(2 \mu \mathrm{g})$.

\section{Acknowledgements}

This work is funded by the European Commission [EA BIOFILMS508866 (NEST)]. The Fund for Scientific Research - Flanders (FWO Vlaanderen) is acknowledged for financial support of P.V.

\section{References}

Barrow, G. I. \& Feltham, R. K. A. (1993). Cowan and Steel's Manual for the Identification of Medical Bacteria, 3rd edn. Cambridge: Cambridge University Press. 
Buchan, A., Gonzalez, J. M. \& Moran, M. A. (2005). Overview of the marine Roseobacter lineage. Appl Environ Microbiol 71, 5665-5677.

Butler, J. H. (1999). Methyl bromide: an introduction to its use, its impacts, and its future. Presented at the 6th IGAC Open Science Conference, Bologna, Italy, 13-17 September 1999. http://www.igac. noaa.gov/newsletter/19/butler.php

Edwards, U., Rogall, T., Blocker, H., Emde, M. \& Bottger, E. C. (1989). Isolation and direct complete nucleotide determination of entire genes. Characterization of a gene coding for $16 \mathrm{~S}$ ribosomal RNA. Nucleic Acids Res 17, 7843-7853.

Ezaki, T., Hashimoto, Y. \& Yabuuchi, E. (1989). Fluorometric deoxyribonucleic acid-deoxyribonucleic acid hybridization in microdilution wells as an alternative to membrane filter hybridization in which radioisotopes are used to determine genetic relatedness among bacterial strains. Int J Syst Bacteriol 39, 224-229.

Faimali, M., Chelossi, E., Garaventa, F., Corrà, C., Greco, G. \& Mollica, A. (2008). Evolution of oxygen reduction current and biofilm on stainless steels cathodically polarised in natural aerated seawater. Electrochim Acta 54, 148-153.

González, J. M., Simo, R., Massana, R., Covert, J. S., Casamayor, E. O., Pedros-Alio, C. \& Moran, M. A. (2000). Bacterial community structure associated with a dimethylsulfoniopropionate-producing north atlantic algal bloom. Appl Environ Microbiol 66, 4237-4246.

Martens, T., Heidorn, T., Pukall, R., Simon, M., Tindall, B. J. \& Brinkhoff, T. (2006). Reclassification of Roseobacter gallaeciensis RuizPonte et al. 1998 as Phaeobacter gallaeciensis gen. nov., comb. nov., description of Phaeobacter inhibens sp. nov., reclassification of Ruegeria algicola (Lafay et al. 1995) Uchino et al. 1999 as Marinovum algicola gen. nov., comb. nov., and emended descriptions of the genera Roseobacter, Ruegeria and Leisingera. Int J Syst Evol Microbiol 56, 1293-1304.

Mast, J., Nanbru, C., Van Den Berg, T. \& Meulemans, G. (2005). Ultrastructural changes of the tracheal epithelium after vaccination of day-old chickens with the La Sota strain of Newcastle disease virus. Vet Pathol 42, 559-565.

Mergaert, J., Verhelst, A., Cnockaert, M. C., Tan, T. L. \& Swings, J. (2001). Characterization of facultative oligotrophic bacteria from polar seas by analysis of their fatty acids and $16 \mathrm{~S}$ rDNA sequences. Syst Appl Microbiol 24, 98-107.

Mesbah, M., Premachandran, U. \& Whitman, W. B. (1989). Precise measurement of the $\mathrm{G}+\mathrm{C}$ content of deoxyribonucleic acid by highperformance liquid chromatography. Int J Syst Bacteriol 39, 159-167.

Pitcher, D. G., Saunders, N. A. \& Owen, R. J. (1989). Rapid extraction of bacterial genomic DNA with guanidium thiocyanate. Lett Appl Microbiol 8, 151-156.

Rademaker, J. L., Hoste, B., Louws, F. J., Kersters, K., Swings, J., Vauterin, L., Vauterin, P. \& De Bruijn, F. J. (2000). Comparison of AFLP and rep-PCR genomic fingerprinting with DNA-DNA homology studies: Xanthomonas as a model system. Int J Syst Evol Microbiol 50, 665-677.

Reichenbach, H. \& Dworkin, M. (1981). Introduction to the gliding bacteria. In The Prokaryotes, vol. 1, pp. 315-327. Edited by M. P. Starr, H. Stolp, H. G. Trüper, A. Balows \& H. G. Schlegel. Berlin: Springer.

Ruiz-Ponte, C., Cilia, V., Lambert, C. \& Nicolas, J. L. (1998). Roseobacter gallaeciensis sp. nov., a new marine bacterium isolated from rearings and collectors of the scallop Pecten maximus. Int J Syst Bacteriol 48, 537-542.

Saitou, N. \& Nei, M. (1987). The neighbor-joining method: a new method for reconstructing phylogenetic trees. Mol Biol Evol 4, 406425.

Schaefer, J. K., Goodwin, K. D., Mcdonald, I. R., Murrell, J. C. \& Oremland, R. S. (2002). Leisingera methylohalidivorans gen. nov., sp. nov., a marine methylotroph that grows on methyl bromide. Int J Syst Evol Microbiol 52, 851-859.

Sierra, G. (1957). A simple method for the detection of lipolytic activity of micro-organisms and some observations on the influence of the contact between cells and fatty substrates. Antonie van Leeuwenhoek 23, 15-22.

Tan, T. L. \& Rüger, H.-J. (1999). Enrichment, isolation, and Biolog metabolic fingerprints of oligotrophic bacteria from the Antarctic Ocean. Arch Hydrobiol Spec Issues Adv Limnol 54, 255-272.

Thompson, J. D., Gibson, T. J., Plewniak, F., Jeanmougin, F. \& Higgins, D. G. (1997). The CLUSTAL_X windows interface: flexible strategies for multiple sequence alignment aided by quality analysis tools. Nucleic Acids Res 25, 4876-4882.

Vandecandelaere, I., Nercessian, O., Segaert, E., Achouak, W., Mollica, A., Faimali, M., De Vos, P. \& Vandamme, P. (2008). Alteromonas genovensis sp. nov., isolated from a marine electroactive biofilm and emended description of Alteromonas macleodii Baumann et al. 1972 (Approved Lists 1980). Int J Syst Evol Microbiol 58, 25892596.

Versalovic, J., Schneider, M., de Bruijn, F. J. \& Lupski, J. R. (1994). Genomic fingerprinting of bacteria using repetitive sequence-based polymerase chain reaction. Methods Mol Cell Biol 5, 25-40.

Wayne, L. G., Brenner, D. J., Colwell, R. R., Grimont, P. A. D., Kandler, O., Krichevsky, M. I., Moore, L. H., Moore, W. E. C., Murray, R. G. E. \& other authors (1987). International Committee on Systematic Bacteriology. Report of the ad hoc committee on reconciliation of approaches to bacterial systematics. Int J Syst Bacteriol 37, 463-464.

Yoon, J. H., Kang, S. J., Lee, S. Y. \& Oh, T. K. (2007). Phaeobacter daeponensis sp. nov., isolated from a tidal flat of the Yellow Sea in Korea. Int J Syst Evol Microbiol 57, 856-861.

Yvon, S. A. \& Butler, J. H. (1996). An improved estimate of the oceanic lifetime of atmospheric $\mathrm{CH}_{3} \mathrm{Br}$. Geophys Res Lett 23, 53-56. 